\title{
Uji Cemaran Mikroba Dalam Susu Kedelai Tanpa Merek Di Kecamatan Jaya Baru Kota Banda Aceh Secara Total Plate Count (TPC)
}

\author{
Yuni Dewi Safrida ${ }^{1}{ }^{*}$, Raihanaton $^{2}$, Ananda $^{3}$ \\ 1,2,3 Akademi Analis Farmasi dan Makanan Banda Aceh \\ *Koresponden Email: yunidewi_safrida@yahoo.com
}

Diterima: 19 Desember 2018

Disetujui : 5 Januari 2019

\begin{abstract}
Soy Milk is white-yellow liquid or kind of beverage that produced by home Industry which should shown about its quality and hygienic to prevented from microba. The purpose of this research is to find out the level of Microba contamination from No-Brand Soy Milk that sold in Jaya Baru Banda Aceh. This research conducted in May 7 th -12 th 2018 at AKAFARMA Laboratory, Banda Aceh. The sample was No-Brand Soy Milk that taken from six different places and analyzed by using Random Sampling. It was a descriptive research and using TPC as the method. The result shown that first LT TPC was $23 \times 106$ colony $/ \mathrm{ml}$, second $\mathrm{E}$ was $49 \times 106$ colony $/ \mathrm{ml}$, third LD was $86 \times 106$ colony $/ \mathrm{ml}$, forth B was $28 \times 107 \mathrm{colony} / \mathrm{ml}$, fifth LB was $26 \times 106$ colony $/ \mathrm{ml}$ and the last PBC was $50 \times 105$ colony $/ \mathrm{ml}$, it can be conclude that the sixth-samples of Soy Milk that sold In Jaya Baru, Banda Aceh were not eligible to SNI Standard, No.06.8-7388-2009 that has 5×104 colony/ml as its TPC toward the Soy Milk extract.
\end{abstract}

Keywords: Microba-prevented, Soy Milk, Total Plate Count (TPC)

\begin{abstract}
Abstrak
Susu kedelai merupakan cairan putih kekuningan hasil dari kegiatan pengolahan produk rumah tangga yang harus diperhatikan kualitas higienis sehingga tidak tercemar oleh mikroba. Penelitian uji cemaran mikroba dalam susu kedelai tanpa merek di Kecamatan Jaya Baru Kota Banda Aceh bertujuan untuk mengetahui tingkat cemaran mikroba dalam susu kedelai tanpa merek yg di jual di Kecamatan Jaya Baru Kota Banda Aceh. Penelitian ini dilakukan pada tanggal 7-12 Mei 2018 di Laboratorium (AKAFARMA) Banda Aceh. Sampel dalam penelitian ini adalah susu kedelai tanpa merek dari enam tempat yang berbeda yang ada di Kecamatan Jaya Baru yang di ambil secara Random Sampling. Penelitian ini bersifat deskriftif dilakukan dengan metode Total Plate Count (TPC). Hasil dari keenam sampel diperoleh TPC yaitu LT sebanyak $23 \times 106$ koloni $/ \mathrm{ml}$, E 49×106 koloni/ml, LD 86×106 koloni/ml, B 28×107 koloni/ml, LB 26×106 koloni $/ \mathrm{ml}$, dan PBC $50 \times 105 \mathrm{koloni} / \mathrm{ml}$, sehingga dari keenam sampel susu kedelai yang dijual dikecamatan Jaya Baru Kota Banda Aceh tidak memenuhi syarat yang telah ditetapkan oleh (SNI) No.06.8-7388-2009 yaitu 5×104 koloni/ml tentang sari susu kedelai.
\end{abstract}

Kata Kunci: Cemaran Mikroba, Susu Kedelai, Total Plate Count (TPC).

\section{Pendahuluan}

Kedelai merupakan bahan pangan yang mempunyai kandungan protein lebih besar dibandingkan dengan beras, jagung, tepung singkong dan yang lainnya serta mempunyai sifat mudah rusak dan membusuk, sehingga mutu atau kualitasnya mudah menurun (Koswara, 2006). Kondisi ini yang mendorong produsen kedelai untuk menciptakan produk yang menggunakan bahan baku kedelai, salah satunya adalah susu kedelai (Soeparno et al, 2011).

Susu kedelai adalah bahan yang diperlukan oleh tubuh seperti protein, lemak, karbohidrat, vitamin dan mineral. Susu kedelai sangat baik untuk dikonsumsi karena

mempunyai nilai gizi yang tinggi (Nuning, 2011). Disamping nilai gizi yang tinggi susu kedelai juga dapat menjadi sebagai media yang baik untuk pertumbuhan berbagai macam mikroorganisme, baik mikroorganisme yang menguntungkan maupun mikroorganisme yang dapat membahayakan manusia (Pelczar dan Chan, 2005).

Komposisi kimia susu kedelai yang lengkap seperti lemak, laktosa, protein, dan lain-lainnya memungkinkan adanya anggapan bahwa susu kedelai berperan sebagai medium yang baik bagi pertumbuhan mikroba merugikan. Susu kedelai yang dihasilkan baru terjadi kontaminasi oleh mikroba. Oleh karena itu, susu kedelai yang diperoleh sesudah proses pengolahan dikhawatirkan mengandung sejumlah bakteri pencemar yang macam dan jumlahnya tergantung pada lingkungan, patologi sanitasi lingkungan dan alat serta bahan pengolah lainnya yang 
Tabel 1. Komposisi susu kedelai

\begin{tabular}{cc}
\hline Komposisi Susu kedelai & Susu kedelai \\
\hline Air (\%) & 88,60 \\
Kalori (kkal) & 52,99 \\
Protein (\%) & 4,40 \\
Karbohidrat (\%) & 3,80 \\
Lemak (\%) & 2,50 \\
Vit. B1 (\%) & 0,04 \\
Vit. B2 (\%) & 0,02 \\
Vit. A (\%) & 0,02 \\
Kalsium (mg) & 15 \\
Fosfor (mg) & 49 \\
Natrium (mg) & 2 \\
Besi (mg) & 1,20 \\
Asam lemak jenuh (\%) & $40-48$ \\
Asam lemak tak jenuh (\%) & $52-60$ \\
Kolesterol (mg) & 0 \\
Abu (g) & 0,5 \\
\hline
\end{tabular}

Sumber : Koswara, 2006

berhubungan dengan pengumpulan, penyimpanan dan transportasi susu kedelai.Alasan susu kedelai disukai mikroba antara lain :

1. PH susu mendekati normal sekitar 6, 6-6, dan 8 .

2. Susu kedelai mengandung gizi yang sangat baik untuk pertumbuhan makhluk hidup termasuk mikroba.

3. Kadar air yang tinggi sekitar $85 \%$. Jumlah bakteri dalam susu kedelai dapat dipengaruhi oleh beberapa factor baik yang berasal dari bahan kedelai itu sendiri (faktor intrinsik), maupun yang berasal dari luar (faktor ekstrinsik) (Soeparno et al., 2011).

Berdasarkan jumlah bakteri dalam air susu, kualitas susu di negara-negara barat dan negara-negara maju lainnya digolongkan menjadi 2 macam, yaitu :

1. Susu dengan kualitas baik atau kualitas A (No. 1)

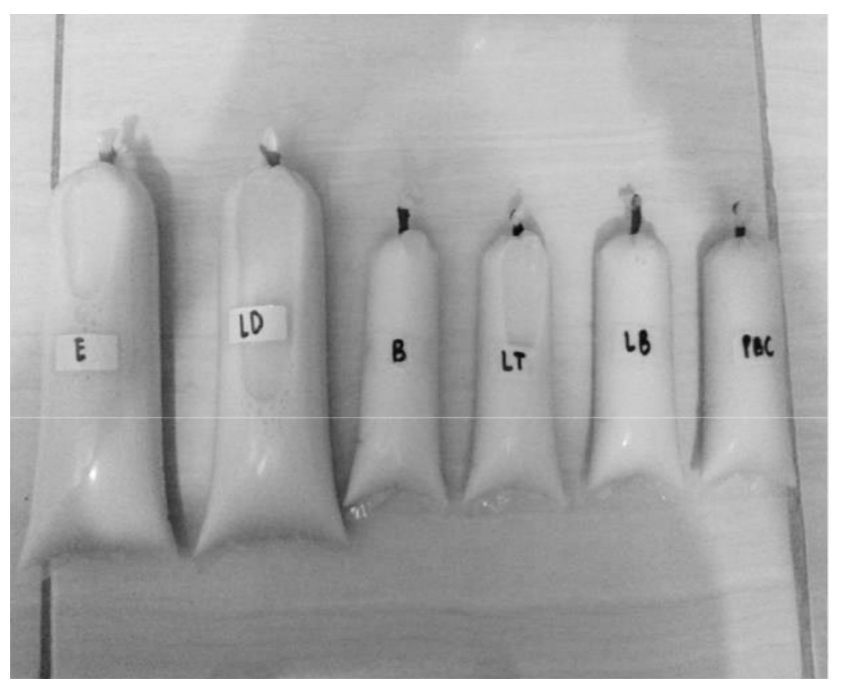

Gambar 1. Susu kedelai tanpa merek jumlah bakteri yang terdapat dalam susu segar tidak lebih dari 10.000/ml.

2. Susu Kualitas B (No, 2) jika jumlah bakterinya anatara 100.000-1.000.000/ml dan jumlah bakteri koliform tidak lebih dari $10 / \mathrm{ml}$ (Hadiwiyoto, 1994).

Mikroorganisme yang menguntungkan dalam susu kedelai adalah Lactobacillus bulgaricus dan Streptococcus thermophillus, yang dapatmenguraikan gula susu (laktosa) menjadi asam laktat (Ramona, 2007). Sedangkan bakteri yang membahayakan yaitu bakteri Escherichia coli dan coliform, apabila daya tahan tubuh seseorang menurun jika masuk E. coli dalam jumlah banyak dapat membahayakan kesehatan yaitu akan menyebabkan diare (Helpida, 2013). Bakteri E. coli adalah organisme yang hidup di dalam pencernaan manusia. Bakteri E. coli dipakai sebagai organisme indikator karena mudah dilihat dengan cara sederhana. Sedangkan coliform merupakan suatu kelompok bakteri yang digunakan sebagai indikator adanya polusi kotoran dan kondisi yang tidak baik terhadap air, makanan dan susu (Pelczar, 2005).

Kontaminasi mikroorganisme di dalam air susu kedelai dapat diperoleh dari penggunaan alat-alat yang kotor, kotoran di sekitar wadah pengolahan dan dapat juga berasal dari bahan baku yang tidak hiegenis serta debu atau faktor lain yang menyebabkan terjadinya kontaminasi terhadap air susu kedelai tersebut (Suprihatin dan Adriyani, 2008). Adanya kontaminasi tersebut menyebabkan kerusakan pada kualitas susu kedelai sehingga tidak layak untuk diminum (Warisno dan Dahana, 2010).

Pada umumnya industri pengolahan susu kedelai merupakan industri rumah tangga dengan permodalan terbatas, pengetahuan sanitasi dan higiene yang rendah serta pengolahan masih dilakukan secara manual sehingga berpotensi terjadi kontaminasi bakteri patogen. Sumber kontaminasi bakteri patogen dapat terjadi melalui bahan baku, bahan pembantu, bahan tambahan, bahan pengemas, peralatan dan lingkungan serta pekerja. Kontaminasi terhadap air susu kedelai dapat membahayakan kesehatan (Infeksi Oportunistik) yaitu akan menyebabkan diare (Harnita, 2008).

Mikrobiologi air sangat bermanfaat untuk menentukan kelayakan dan kondisi air tersebut dalam hal layak untuk diminum atau air bersih. Peran air sangat penting bagi kehidupan di dunia karena jika tidak ada air seluruh makhluk hidup di bumi ini tidak dapat hidup. Air bersih yaitu air yang tidak berwarna, tidak berbau dan tidak berasa. Air yang bersih belum tentu layak diminum. Pemeriksaan derajat pencemaran 


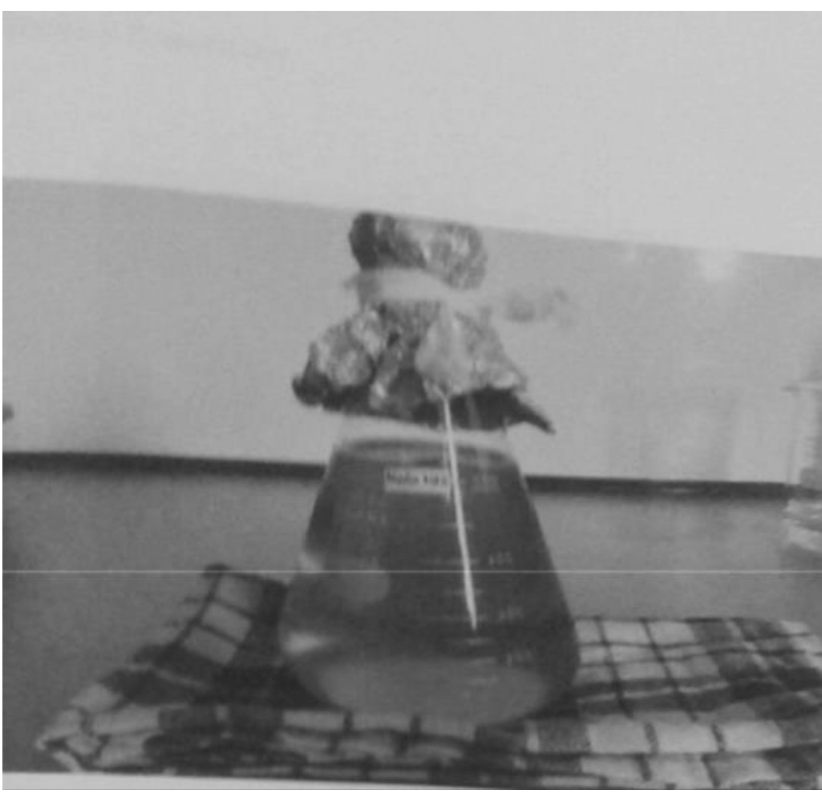

Gambar 2. Media MHA

air secara mikrobiologi umumnya ditunjukkan dengan kehadiran bakteri indikator seperti coliform dan fecal coli (Ramona, 2007).

Bakteri coliform sebagai suatu kelompok dicirikan sebagai bakteri berbentuk batang gram negatif, tidak membentuk spora, aerobik dan anaerobik fakultatif yang memfermentasi laktose dengan menghasilkan asam dan gas dalam waktu 48 jam pada suhu $35^{\circ}$ C (Radji,2010). Kelompok bakteri coliform antara lain Eschericiacoli, Enterrobacter aerogenes, dan Citrobacter fruendii. Keberadaan bakteri inidalam air minum juga menunjukkan adanya bakteri patogen

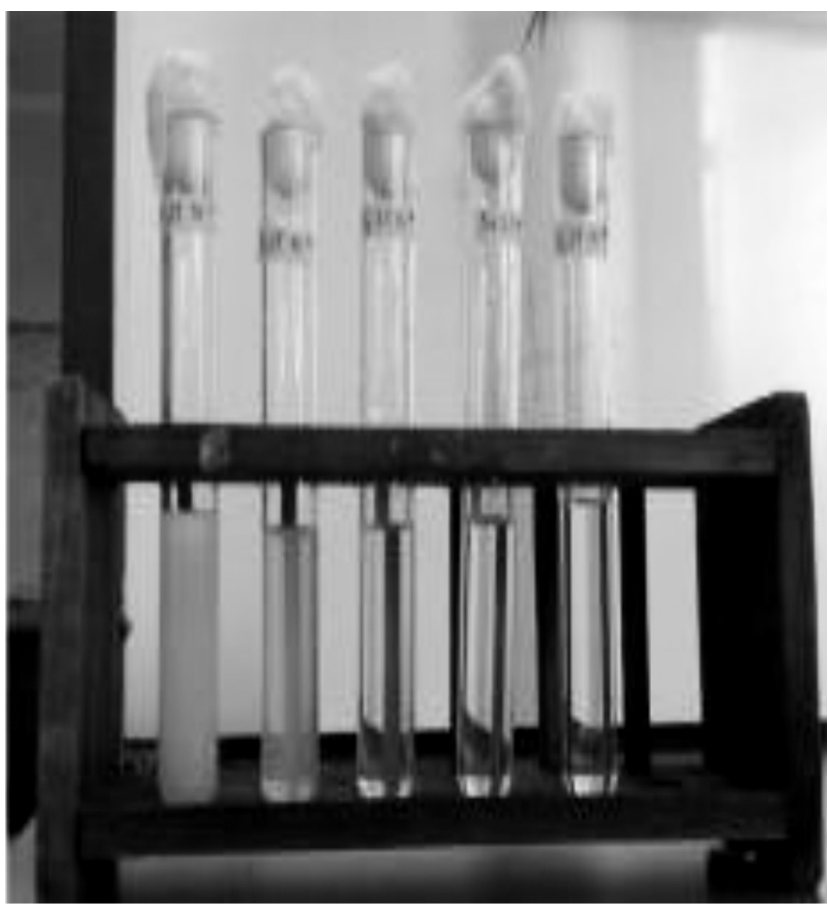

Gambar 3. Pengenceran LT

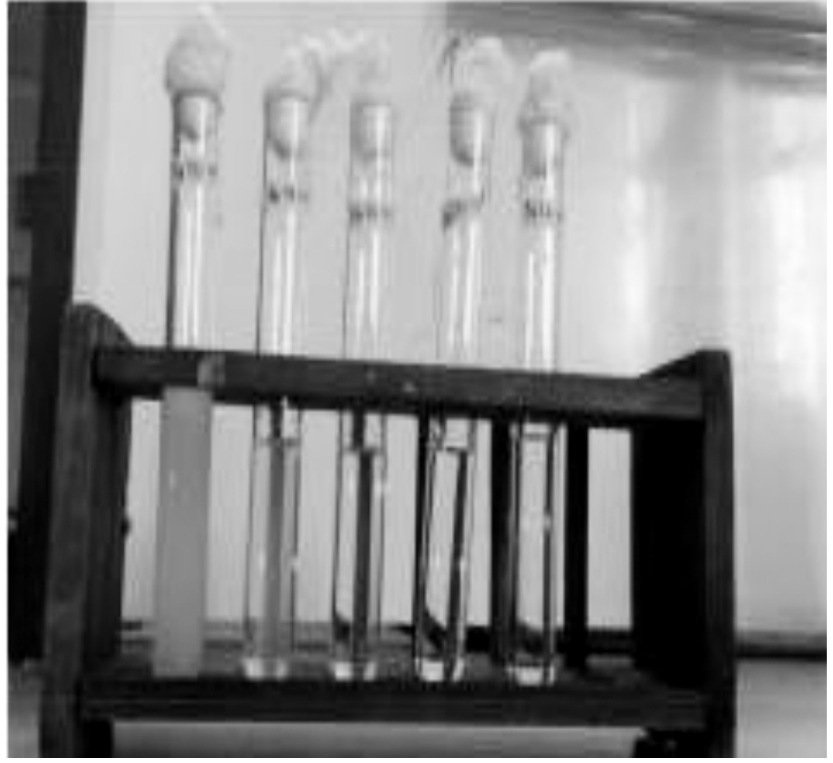

Gambar 4. Pengenceran LD

lain, misalnya Shigella, yang bisa menyebabkan diare hingga muntaber (Suriawiria, 1995). Jadi, bakteri coliform adalah indikator kualitas air. Semakin sedikit kandungan coliform, maka kualitas air semakin baik. Bakteri colifrom atau enterobacteriaceae merupakan kelompok batang gram negatif yang besar dan heterogen, dengan habitat alaminya disalurkan cerna manusia dan hewan (Waluyo, 2005).

Bakteri colifrom bersifat fakultatif aerob atau anaerob, memfermentasikan berbagai karbohidrat, memiliki struktur kompleks antigen, dan menghasilkan berbagai toksin dan faktor virulensi lainnya (Suriawiria, 2008). Bakteri E. coli adalah organisme yang hidup di dalam pencernaan manusia. Bakteri E. coli dipakai sebagai organisme indikator karena mudah dilihat dengancara sederhana. Ditemukannya bakteri E. coli bukan berarti adanya patogen di dalam

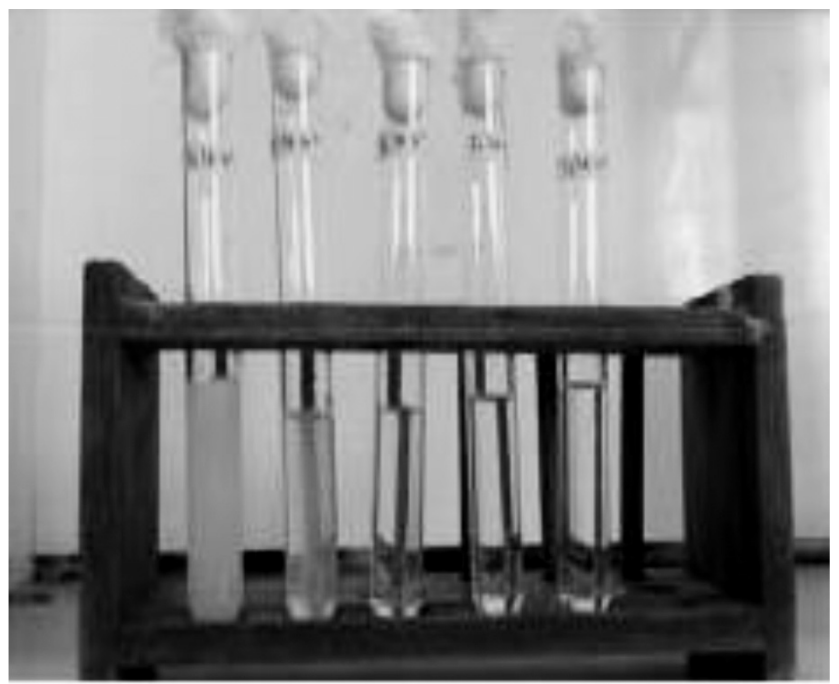

Gambar 5. Pengenceran LB 


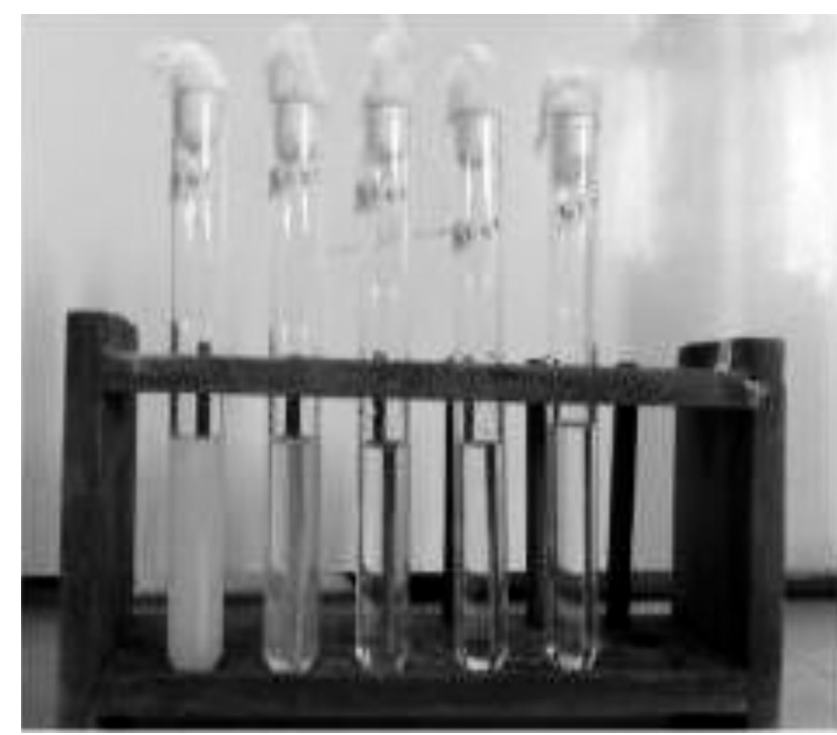

Gambar 6. Pengenceran E

air, tetapi kemungkinan adanya organisme patogen dalam air (Pelczar dan Chan., 2006).

Menurut penelitian Balia dkk (2010) menunjukkan bahwa susu kedelai dari pengolahan rakyat di Lembang Bandung mengandung bakteri total pada susu kedelai adalah $3,70 \times 10^{6} \mathrm{CFU} / \mathrm{ml}$, sedangkan dari susu kedelai pasteurisasi tanpa kemasan di pedagang kaki lima diperoleh jumlah bakteri total $3,45 \times 10^{6}$ $\mathrm{CFU} / \mathrm{ml}$. Hal ini menunjukkan bahwa bakteri total pada susu kedelai ternyata melebihi batas maksimum cemaran yang ditetapkan oleh SNI 01-3830-1995 yaitu 1 X $10^{6} \mathrm{CFU} / \mathrm{ml}$ baik dari pengolahan rakyat skala industri rumah tangga maupun dari pedagang kaki lima. Menurut penelitian Helpida (2013) terdapat cemaran bakteri coliform dan E. coli, jumlah coliform 8,8/100 ml, E. coli $16 / 100 \mathrm{ml}$, dan coliform dan $E$.



Gambar 7. Pengenceran B

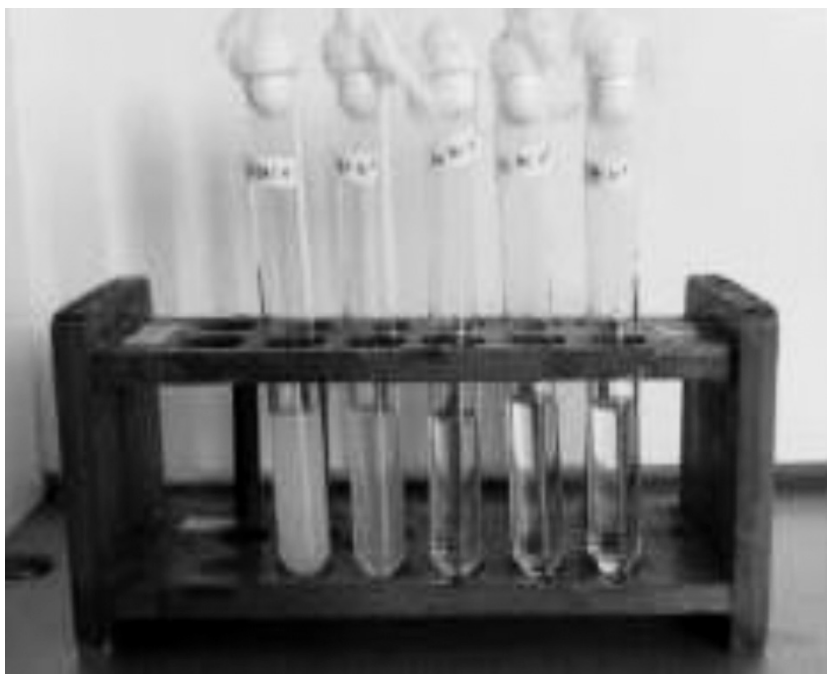

Gambar 8. Pengenceran PBC

coli berjumlah $240 / \mathrm{ml}$, coliform dan E. coli berjumlah $5 / 100 \mathrm{ml}$. Hal ini menunjukkan cemaran bakterinya sudah melebihi batas yang di perbolehkan menurut SNI (1996) yaitu coliform dan E. coli harus 0 untuk susu segar maupun pasteurisasi. Ketetapan Menurut Standard Nasional Indonesia (SNI) No.06.8-73882009 persyaratan cemaran mikroba pada produk sari kedelai yaitu $5 \times 10^{4} \mathrm{koloni} / \mathrm{ml}$.

Angka lempeng total (ALT) atau Total Plate Count (TPC) atau istilah lain adalah Aerobic Plate Count (APC), Standard Plate Count atau Aerobic MikrobialCount (AMC). Didefinisikan sebagai jumlah mikroba (aerobmesofil) dalam suatuproduk, umumnya tidak terkait dengan bahaya keamanan produk, bermanfaat menunjukkan kualitas, masa simpan, konstaminasi dan status higienis pada saat proses produksi (Jawetz, 1996).

Oleh karena itu, dilakukan penelitian Uji Cemaran Mikroba Dalam Susu Kedelai Tanpa Merek Di Kecamatan Jaya Baru Kota Banda Aceh Secara Total Plate Count (TPC).

\section{Metodologi Penelitian}

\subsection{Alat dan Bahan}

Alat yang digunakan pada penelitian ini adalah tabung reaksi, erlemeyer, cawan petri, kapas steril, Bunsen, pipet ukur, timbangan analitik, batang pengaduk, gelas ukur, hote plate, autoclave, beaker glass, spidol, penggaris, rak tabung, pipet tetes, incubator, kertas koran/plano, spatula dan alumuniun foil. Bahan yang digunakan dalam penelitian ini adalah susu kedelai, Mueller Hinton Agar (MHA), alkohol dan aquadest.

\subsection{Prosedur Penelitian}

Dihitung 25,5 gram MAH dimasukkan kedalam Erlenmeyer. Ditambahkan aquadest sebanyak $750 \mathrm{ml}$. 


\section{Cara Kerja Uji Total Plate Count (TPC)}

Dipipet $1 \mathrm{ml}$ dari setiap pengenceran $10^{-1}, 10^{-2} \mathrm{dst}$ dan dimasukkan ke dalam cawan petri steril. Dilakukan secara duplo untuk setiap

pengenceran
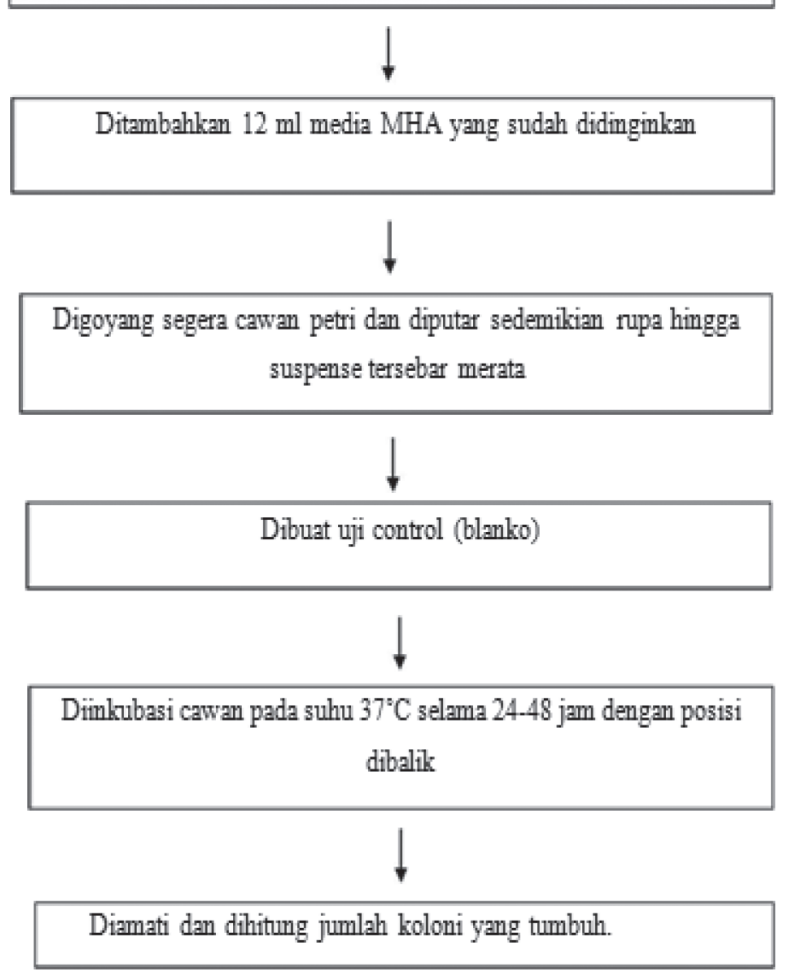

Gambar 9. Diagram alir uji TPC

Dipanaskan sampai larutan mendidih. Disterilkan selama 15 menit pada suhu $121^{\circ} \mathrm{C}$.

\subsection{Preparasi Sampel}

Disiapkan 5 tabung reaksi yang masing-masing telah di isi dengan $9 \mathrm{ml}$ aquadest. Diambil $1 \mathrm{ml}$ sampel dipipet dan dimasukkan ke dalam $9 \mathrm{ml}$ larutan aquadest (pengenceran $10^{-1}$ ). Dari suspense pengenceran $10^{-1}$ dipipet $1 \mathrm{ml}$ ke dalam tabung reaksi $9 \mathrm{ml}$ aquadest (pengenceran $10^{-2}$ ). Dibuat pengenceran selanjutnya hingga pengenceran $10^{-5}$.

Jumlah koloni yang diperoleh dari pengamatan dibandingkan dengan nilai persyaratan Menurut Standard Nasional Indonesia (SNI) No.06.8-73882009 persyaratan cemaran mikroba pada produk sari kedelai yaitu $5 \times 10^{4} \mathrm{koloni} / \mathrm{ml}$.

\section{Perhitungan Koloni}

$$
N=\frac{\sum C}{[(1 \times n 1)+(0,1 \times n 2)] \times(d)}
$$

Keterangan :

$\mathrm{N}=$ Jumlah koloni produk, dinyatakan dalam koloni per $\mathrm{ml}$ atau koloni per $\mathrm{g}$.

$\Sigma \mathrm{C}=$ Jumlah koloni pada semua cawan yang dihitung.

$\mathrm{n}_{1} \quad=$ Jumlah cawan pada pengenceran pertama yang dihitung.

$\mathrm{n}_{2} \quad=$ Jumlah cawan pada pengenceran kedua yang dihitung.

$\mathrm{D}=$ Pengenceran pertama yang dihitung.

Metode perhitungan cawan didasarkan pada anggapan bahwa setiap sel yang dapat hidup akan

Tabel 2. Hasil uji cemaran mikroba pada susu kedelai tanpa merek yang beredar di Kecamatan Jaya Baru Kota Banda Aceh.

\begin{tabular}{|c|c|c|c|c|}
\hline \multirow{2}{*}{$\begin{array}{c}\text { Kode } \\
\text { Sampel }\end{array}$} & \multirow[t]{2}{*}{ Pengenceran } & \multicolumn{2}{|c|}{$\begin{array}{c}\text { Jumlah koloni } \\
(\mathrm{Kol} / \mathrm{ml})\end{array}$} & \multirow{2}{*}{$\begin{array}{c}\text { TPC } \\
\text { (koloni/ml) }\end{array}$} \\
\hline & & Cawan 1 & Cawan 2 & \\
\hline \multirow{7}{*}{$\mathrm{LT}$} & $10^{-1}$ & TBUD & TBUD & \\
\hline & $10^{-2}$ & TBUD & TBUD & \\
\hline & $10^{-3}$ & TBUD & TBUD & $23 \times 10^{6}$ \\
\hline & $10^{-4}$ & TBUD & TBUD & \\
\hline & $10^{-5}$ & 236 & 230 & \\
\hline & $10^{-1}$ & TBUD & TBUD & \\
\hline & $10^{-2}$ & TBUD & TBUD & \\
\hline \multirow[t]{5}{*}{$\mathrm{E}$} & $10^{-3}$ & TBUD & TBUD & $49 \times 10^{6}$ \\
\hline & $10^{-4}$ & TBUD & TBUD & \\
\hline & $10^{-5}$ & 50 & 47 & \\
\hline & $10^{-1}$ & TBUD & TBUD & \\
\hline & $10^{-2}$ & TBUD & TBUD & \\
\hline \multirow[t]{5}{*}{ LD } & $10^{-3}$ & TBUD & TBUD & $86 \times 10^{6}$ \\
\hline & $10^{-4}$ & TBUD & TBUD & \\
\hline & $10^{-5}$ & 98 & 73 & \\
\hline & $10^{-1}$ & TBUD & TBUD & \\
\hline & $10^{-2}$ & TBUD & TBUD & \\
\hline \multirow[t]{4}{*}{$\mathrm{B}$} & $10^{-3}$ & TBUD & TBUD & $2,8 \times 10^{6}$ \\
\hline & $10^{-4}$ & 67 & 200 & \\
\hline & $10^{-5}$ & 147 & 201 & \\
\hline & $10^{-1}$ & TBUD & TBUD & \\
\hline \multirow[t]{5}{*}{ LB } & $10^{-2}$ & TBUD & TBUD & \\
\hline & $10^{-3}$ & TBUD & TBUD & $26 \times 10^{6}$ \\
\hline & $10^{-4}$ & TBUD & TBUD & \\
\hline & $10^{-5}$ & 271 & 241 & \\
\hline & $10^{-1}$ & TBUD & TBUD & \\
\hline \multirow[t]{4}{*}{$\mathrm{PBC}$} & $10^{-2}$ & TBUD & TBUD & \\
\hline & $10^{-3}$ & TBUD & TBUD & $50 \times 10^{5}$ \\
\hline & $10^{-4}$ & 32 & 31 & \\
\hline & $10^{-5}$ & 42 & TBUD & \\
\hline \multirow[t]{2}{*}{ Blanko } & 1 & 0 & 0 & \\
\hline & 2 & 0 & 0 & \\
\hline
\end{tabular}

Keterangan :

TBUD $=$ Terlalu Banyak Untuk Dihitung 

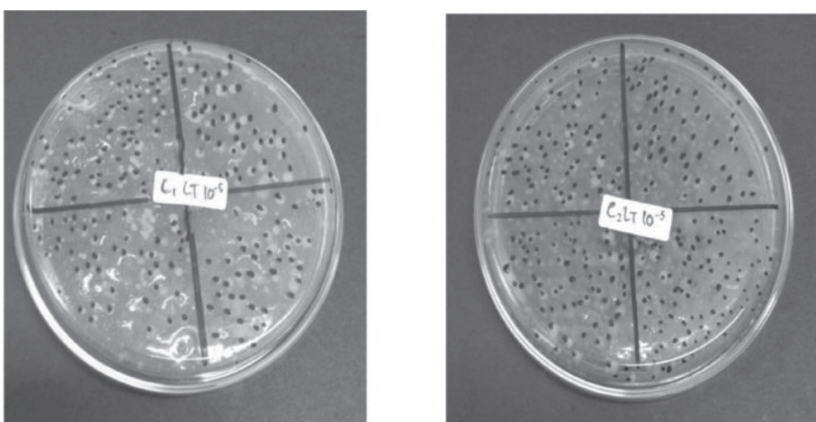

Gambar 9. Pengenceran LT 10-5

berkembang menjadi satu koloni. Jadi jumlah koloni yang muncul pada cawan merupakan suatu indeks bagi jumlah organisme yang dapat hidup yang terkandung dalam sampel dan mencawankan hasil pengenceran tersebut. Setelah inkubasi, jumlah koloni masingmasing cawan diamati. Untuk memenuhi persyaratan statistik, cawan yang dipilih untuk perhitungan koloni ialah yang mengandung koloni antara 30 sampai 300 koloni (Thayib dan Amar, 1986).

Prinsip pengujian Angka Lempeng Total menurut Metode Analis Mikrobiologi (MA PPOM 61/MK/06) yaitu pertumbuhan koloni bakteri aerob mesofil setelah cuplikan diinokulasikan pada media lempeng agar dengan cara tuang dan diinkubasi pada suhu yang sesuai. Pada pengujian Angka Lempeng Total digunakan Pepton Dilution Fluid (PDF) sebagai pengencer sampel dan menggunakan Plate Count Agar (PCA) sebagai media padatnya. Digunakan juga pereaksi khusus Tri Phenyl Tetrazolium Chlotide 0,5\% (TTC) (Dirjen POM, 2000).

Cara ALT ini yang paling umum digunakan untuk perhitungan jumlah mikroba. Dasarnya ialah membuat suatu seri pengenceran bahan dengan kelipatan 10 masing-masing pengenceran diambil $1 \mathrm{cc}$ atau $1 \mathrm{ml}$ dan dibuat taburan dalam petridish (pour plate) dengan medium agar yang macam caranya tergantung pada macamnya mikroba. Setelah diinkubasikan dihitung koloni tiap petridish dapat ditentukan jumlah bakteri tiap cc atau gram contoh, yaitu dengan mengalikan jumlah koloni dengan kebalikan pengencerannya, misalnya untuk pengenceran 1:10.000 terdapat
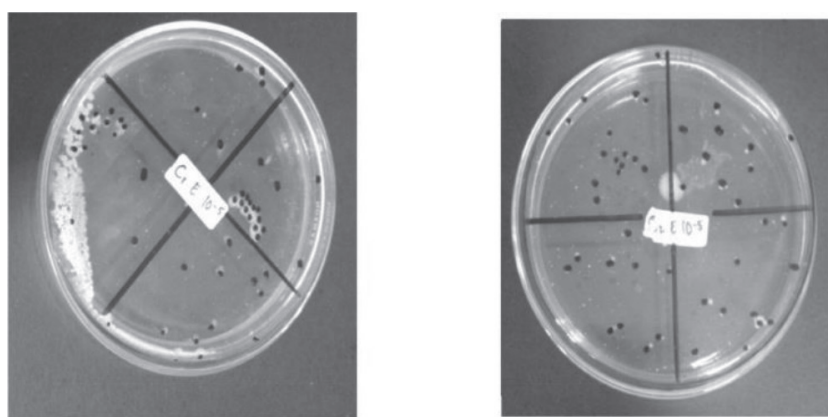

Gambar 10. Pengenceran E 10-5
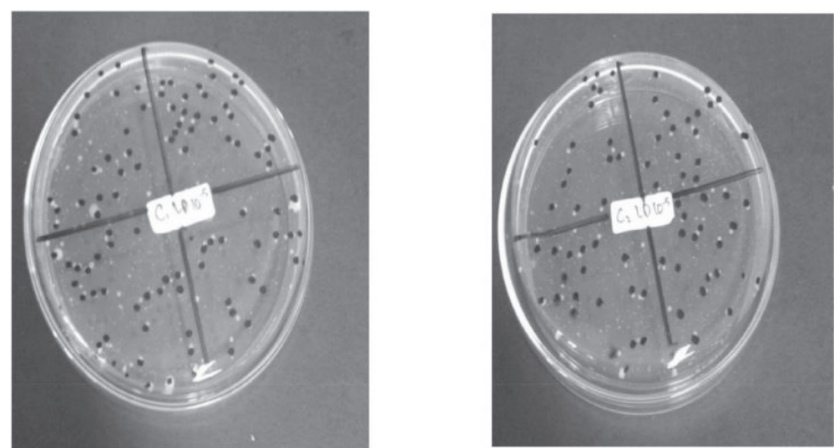

Gambar 11. Pengenceran LD 10-5

45 koloni bakteri maka tiap cc atau gram bahan mengandung 450.000 bakteri. Untuk membantu menghitung jumlah koloni dalam petridish dapat digunakan colony counter yang biasanya dilengkapi electronic register (Thayib, 1989).

\section{Hasil dan Pembahasan}

Hasil penelitian cemaran mikroba pada susu kedelai tidak bermerek yang beredar di Kecamatan Jaya Baru Kota Banda Aceh didapatkan hasil TPC adalah pada sampel LT pengerceran $10^{-1}, 10^{-2}, 10^{-3}, 10^{-4}$ TBUD dan pengenceran $10^{-5}$ didapat cawan satu $236 \mathrm{koloni} / \mathrm{ml}$, cawan dua $230 \mathrm{koloni} / \mathrm{ml}$ dengan total TPC sebanyak $23 \times 10^{6} \mathrm{koloni} / \mathrm{ml}$. Perhitungan dilakukan pada media agar yang jumlah populasi mikrobanya antara 30-300 koloni. Bila jumlah populasi kurang dari 30 koloni akan menghasilkan perhitungan yang kurang teliti secara statistic, namun bila lebih dari 300 koloni akan menghasilkan hal yang sama karena terjadi persaigan diantara koloni. Perhitungan populasi mikroba dapat dilakukan setelah masa inkubasi yang umumnya
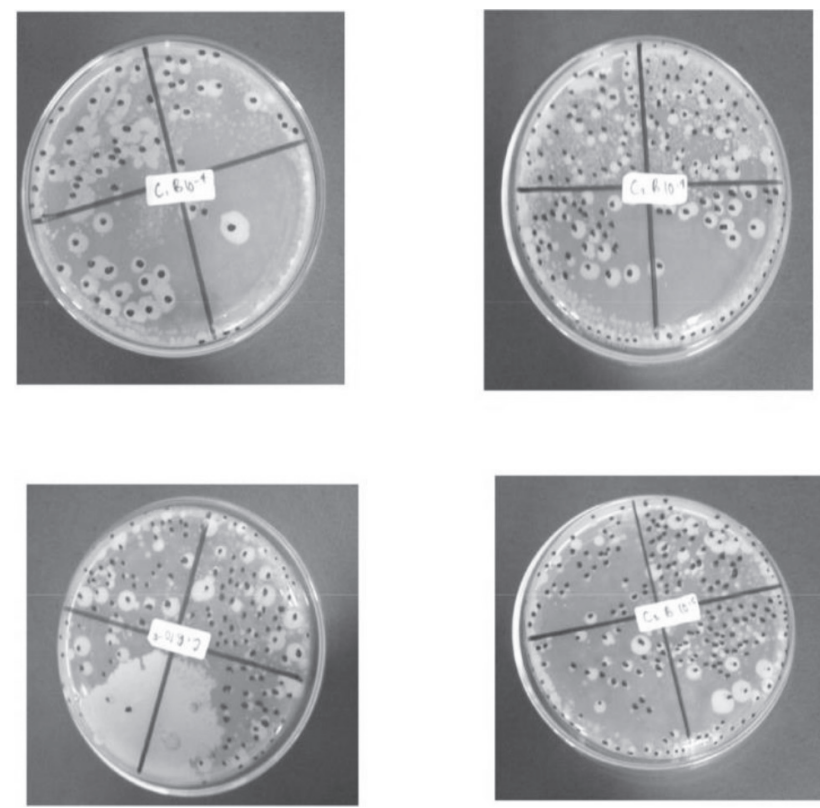

Gambar 12. Pengenceran LD 10-4 dan 10-5 

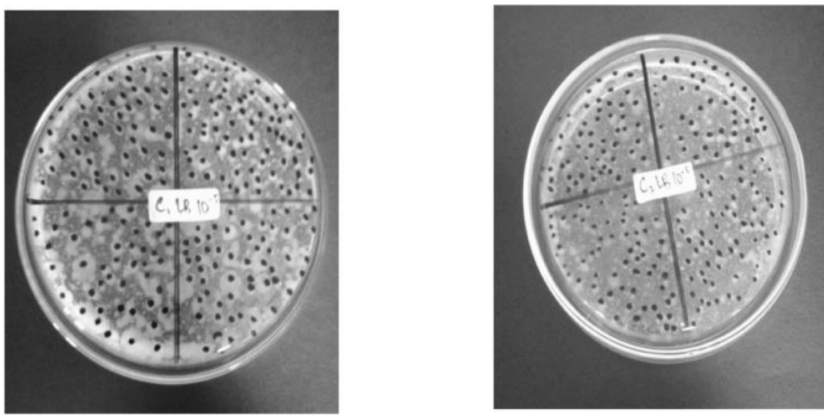

Gambar 13. Pengenceran LB 10-5

membutuhkan waktu 24 jam atau lebih (Waluyo, 2005).

Pada sampel E pengenceran $10^{-1}, 10^{-2}, 10^{-3}, 10^{-4}$ TBUD. Bila jumlah populasi kurang dari 30 koloni akan menghasilkan perhitungan yang kurang teliti secara statistik. Dan pengenceran $10^{-5}$ didapat cawan satu $50 \mathrm{koloni} / \mathrm{ml}$, cawan dua $47 \mathrm{koloni} / \mathrm{ml}$ dengan total TPC sebanyak $49 \times 10^{6} \mathrm{koloni} / \mathrm{ml}$, namun bila lebih dari 300 koloni akan menghasilkan hal yang sama karena terjadi persaigan diantara koloni (Waluyo, 2005).

Pada sampel LD pengerceran $10^{-1}, 10^{-2}, 10^{-3}$, $10^{-4}$ TBUD dan pengenceran $10^{-5}$ didapat cawan satu $98 \mathrm{koloni} / \mathrm{ml}$, cawan dua $73 \mathrm{koloni} / \mathrm{ml}$ dengan total TPC sebanyak $86 \times 10^{6} \mathrm{koloni} / \mathrm{ml}$. Jumlah koloni yang dilihat adalah yang paling sedikit (dapat dihitung) dari pengenceran terkecil kaerena jumlah koloni masingmasing cawan diamati untuk memenuhi persyaratan statistic, cawan yang dipilih untuk perhitungan koloni ialah yang menggandung koloni 30 sampai 300 koloni (Thayib, 1989).

Pada sampel B pengerceran $10^{-1}, 10^{-2}, 10^{-3}$ TBUD. Bila jumlah populasi kurang dari 30 koloni akan menghasilkan perhitungan yang kurang teliti secara statistic. Dan pengenceran $10^{-4}$ didapat cawan satu 67 koloni/ml cawan dua $200 \mathrm{koloni} / \mathrm{ml}$ dan pengenceran $10^{-5}$ didapat cawan satu $147 \mathrm{koloni} / \mathrm{ml}$, cawan dua $201 \mathrm{koloni} / \mathrm{ml}$ dengan total TPC sebanyak $28 \times 10^{7}$ koloni/ml, namun bila lebih dari 300 koloni akan menghasilkan hal yang sama karena terjadi persaigan diantara koloni.

Pada sampel LB pengerceran $10^{-1}, 10^{-2}, 10^{-3}, 10^{-4}$ TBUD dan pengenceran $10^{-5}$ didapat cawan satu 271 koloni/ml, cawan dua $241 \mathrm{koloni} / \mathrm{ml}$ dengan total TPC sebanyak $26 \times 10^{6} \mathrm{koloni} / \mathrm{ml}$. Jumlah koloni yang dilihat adalah yang paling sedikit (dapat dihitung) dari pengenceran terkecil karena jumlah koloni masingmasing cawan diamati untuk memenuhi persyaratan statistic, cawan yang dipilih untuk perhitungan koloni ialah yang mengandung koloni 30 sampai 300 koloni.

Pada sampel PBC pengerceran $10^{-1}, 10^{-2}, 10^{-3}$ TBUD dan pengenceran $10^{-4}$ didapat cawan satu 32 koloni $/ \mathrm{ml}$ cawan dua $31 \mathrm{koloni} / \mathrm{ml}$ dan pengenceran $10^{-5}$ didapat cawan satu $42 \mathrm{koloni} / \mathrm{ml}$, cawan dua TBUD dan total TPC sebanyak $50 \times 10^{5} \mathrm{koloni} / \mathrm{ml}$. Bila lebih dari 300 koloni akan menghasilkan hal yang sama karena terjadi persaigan diantara koloni namun bila jumlah populasi kurang dari 30 koloni akan menghasilkan perhitungan yang kurang teliti secara statistic. Jumlah koloni yang dilihat adalah yang paling sedikit (dapat dihitung) dari pengenceran terkecil. Jadi cawan yang dihitung pada susu kedelai di Kecamatan Jaya Baru yaitu pada konsentrasi $10^{-1}$ dan $10^{-5}$. Kemudian hasil yang diperoleh dari perhitungan dibandingkan dengan nilai persyaratan Menurut Standard Nasional Indonesia (SNI) No.06.8-73882009 persyaratan cemaran mikroba pada produk sari kedelai yaitu $5 \times 10^{4} \mathrm{koloni} / \mathrm{ml}$. Hasil yang diperoleh dalam penelitian ini tidak memenuhi syarat yang telah ditetapkan oleh (SNI) No.06.8-7388-2009

Menurut penelitian Balia (2010) susu kedelai dari pengolahan rakyat di Lembang Bandung mengandung bakteri total pada susu kedelai adalah $3,70 \times 10^{6} \mathrm{CFU} /$ $\mathrm{ml}$, sedangkan dari susu kedelai pasteurisasi tanpa kemasan di pedagang kaki lima diperoleh jumlah bakteri total 3,45 X $10^{6} \mathrm{CFU} / \mathrm{ml}$. Hal ini menunjukkan bahwa bakteri total pada susu kedelai ternyata melebihi batas maksimum cemaran yang ditetapkan oleh SNI 01-3830-1995 yaitu 1 X $10^{6} \mathrm{CFU} / \mathrm{ml}$ baik dari pengolahan rakyat skala industri rumah tangga maupun dari pedagang kaki lima.

Faktor lain yang mempengaruhi keberadaan bakteri pada susu kedelai tanpa merek diduga karena industri pengolahan susu kedelai merupakan industri rumah tangga dengan permodalan terbatas, pengetahuan
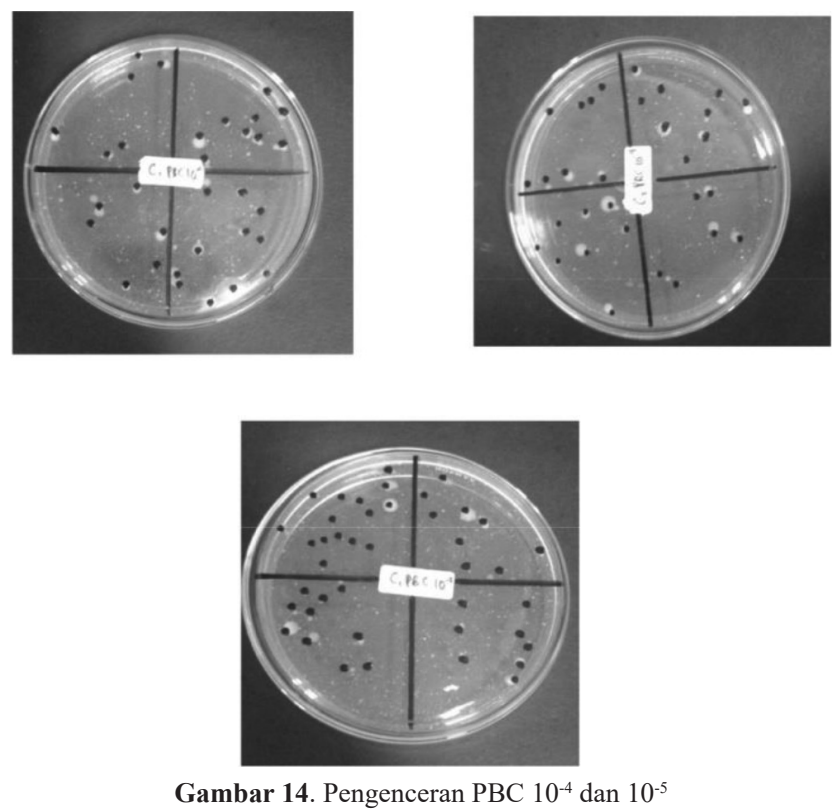

Gambar 14. Pengenceran PBC $10^{-4}$ dan $10^{-5}$ 
sanitasi dan higiene yang rendah serta pengolahan masih dilakukan secara manual sehingga berpotensi terjadi kontaminasi bakteri patogen. Sumber kontaminasi bakteri patogen dapat terjadi melalui bahan baku, bahan pembantu, bahan tambahan, bahan pengemas, peralatan dan lingkungan serta pekerja. Kontaminasi terhadap air susu kedelai dapat membahayakan kesehatan (Infeksi Opertunistik) yaitu akan menyebabkan diare (Soeparno et al., 2011).

\section{Kesimpulan}

Dari hasil penelitian uji cemaran mikroba dalam susu kedelai tanpa merek di Kecamatan Jaya Baru Kota Banda Aceh diperoleh hasil susu kedelai yaitu LT sebanyak $23 \times 10^{6} \mathrm{koloni} / \mathrm{ml}$, E $49 \times 10^{6} \mathrm{koloni} /$ $\mathrm{ml}$, LD $86 \times 10^{6} \mathrm{koloni} / \mathrm{ml}$, B $2,8 \times 10^{6} \mathrm{koloni} / \mathrm{ml}$, LB $26 \times 10^{6} \mathrm{koloni} / \mathrm{ml}$, dan PBC $50 \times 10^{5} \mathrm{koloni} / \mathrm{ml}$. Bahwa Jumlah koloni yang didapat melebihi ambang batas dan tidak memenuhi syarat yang telah ditetapkan oleh (SNI) No.06.8-7388-2009 dengan jumlah koloni yang diperbolehkan dalam sari susu kedelai sebanyak $5 \times 10^{4} \mathrm{koloni} / \mathrm{ml}$.

\section{Saran}

Disarankan untuk melanjutkan penelitian dengan menggunakan metode seperti APM Escherichia coli, salmonella sp, staphylococcus, bacillusceceus, kapang dan khamir.

\section{Ucapan Terima Kasih}

Peneliti mengucapkan terimakasih banyak kepada keluarga dan rekan-rekan sejawat yang telah banyak memberikan dukungan serta bantuan kepada peneliti.

\section{Daftar Pustaka}

Balia, Roostita, Linda Herlina dan Siti Nurahcmah. (2010) 'Keberadaan Khamir pada Produk Fermentasi Susu Kambing dengan Penambahan Sari Kurma Non Pasteurisasi yang Difermentasi Berbagai Starter Bakteri Asam Laktat', Bandung, Jurnal I $1 \mathrm{~m} \mathrm{u}$ Ternak Vol. 10, No 2, Hal:118-121.

Dirjen POM. (2000) 'Parameter Standar Umum Ekstrak Tumbuhan Obat, Cetakan Pertama, Jakarta, Depkes RI.

Hadiwiyoto, S. (1994)'Teori dan Prosedur Pengujian Mutu Susu dan Hasil Olahannya', Edisi II, Penerbit Liberty, Yogyakarta.

Harmita. (2008)'Buku Ajar Analisis Hayati’, Edisi 1, EGC, Jakarta

Helpida. (2013)'Uji Bakteriologis Susu Kedelai Produk Rumah Tangga Yang Di Jual Dipasaran', Fakultas Biologi FMIPA Universitas Negeri
Padang.

Jawetz. (1996)‘Mikrobiologi Kedokteran’, Edisi 1, Terjemahan dari Medical Mikrobiology oleh Eddi Mudihardi, Penerbit Buku Kedokteran ECG, Jakarta.

Koswara, S. (2006)'Isoflavon, Senyawa MultiManfaat Dalam Kedelai', Tersedia dari: http;// ebookpangan.com.

Nuning. (2011)'Analisis Sikap Dan Perilaku Pembaca Surat Kabar Terhadap Iklan Susu Kedelai', Universitas Brawijaya Fakultas Pertanian.

Pelczar dan Chan. (2005)'Dasar-dasar Mikrobiologi’, UI Press: Jakarta.

Ramona. (2007)'Dasar-Dasar Mikrobiologi', Penerbit Erlangga, Jakarta.

Radji Maksum. (2010)'Buku Ajar Mikrobiologi Panduan Mahasiswa Farmasi dan Kedokteran', EGC: Jakarta.

Suriawiria. (1995)'Mikrobiologi Dasar Dalam Praktek. PT Gramedia', Jakarta.

Suriawiria. (2008)'Mikrobiologi Dasar Dalam Praktek', PT Gramedia, Jakarta’

Soeparno, Rihastuti, S., Triatmojodan Indratiningsih.. (2011)'Dasar Teknologi Hasil Ternak', Universitas Gadjah Mada, Yogyakarta.

Suprihatin, B dan Adriyani, R. (2008)'Higiene Sanitasi Depot Air Minum Isi Ulang Di Kecamatan Tanjung Redep Kabupaten Berau Kalimantan Timur', Jurnal Kesehatan Lingkungan, Fakultas Kesehatan (Vol.4, No.2).

Thayib, S. dan Amar, A. (1986)'Petunjuk Praktikum Mikrobiologi Pangan', Fakultas Teknologi Pertanian, Institut Teknologi Indonesia, Bogor.

Waluyo, L. (2005)‘Mikrobiologi Umum', Universitas Muhammadiyah Malang Prees, Malang.

Warisno dan Dahana, K. (2010)'Meraup Untung dari Olahan Kedelai', PT AgroMedia Pustaka, Jakarta. 